\title{
Developing Comic of Human Skeletal System and Its Potential in Improving Junior High School Students' Learning Achievement
}

\author{
Lise Chamisijatin $^{1}$, Rini Dwi Lestari ${ }^{1}$, Husamah $^{1}$, Ahmad Fauzi $^{1}$, Diani Fatmawati ${ }^{1, *}$, Siti Nurhasanah $^{2}$ \\ ${ }^{1}$ Department of Biology Education, Universitas Muhammadiyah Malang, Malang, Indonesia \\ ${ }^{2}$ Department of Biology Education, Postgraduate Program, Universitas Muhammadiyah Malang, Malang, Indonesia
}

Received May 28, 2020; Revised September 7, 2020; Accepted October 24, 2020

\section{Cite This Paper in the following Citation Styles}

(a): [1] Lise Chamisijatin, Rini Dwi Lestari, Husamah, Ahmad Fauzi, Diani Fatmawati, Siti Nurhasanah, "Developing Comic of Human Skeletal System and Its Potential in Improving Junior High School Students' Learning Achievement," Universal Journal of Educational Research, Vol. 8, No. 12, pp. 6383-6393, 2020. DOI: 10.13189/ujer.2020.081204.

(b): Lise Chamisijatin, Rini Dwi Lestari, Husamah, Ahmad Fauzi, Diani Fatmawati, Siti Nurhasanah (2020). Developing Comic of Human Skeletal System and Its Potential in Improving Junior High School Students' Learning Achievement. Universal Journal of Educational Research, 8(12), 6383-6393. DOI: 10.13189/ujer.2020.081204.

Copyright $\odot 2020$ by authors, all rights reserved. Authors agree that this article remains permanently open access under the terms of the Creative Commons Attribution License 4.0 International License

\begin{abstract}
Learning media plays an important role in increasing students' interest and motivation in science. This study aimed at analyzing the feasibility of comic as a learning media for human musculoskeletal system topic as well as analyzing its potential in improving the learning outcomes of eighth graders. The Gall and Borg [1] development model was chosen as the basis of the study procedure. Interview sheets, validation questionnaires, student response sheets, and test sheets were used as the instruments in data collection. The comic validation results gained from the both content and media experts were $82 \%$ and $80 \%$ respectively, which means that the comic developed was categorized as 'good'. Moreover, the results of pilot test done showed that the students' learning outcomes increased from 69 to 95 , while the students' response has reached $96.77 \%$. In addition, the large-scale trial results indicated that the students' learning outcomes have significantly increased $(Z=7.296, p=0.000)$. The findings in this study indicate that the comic learning media developed was potential in improving the quality of biology learning process in junior high schools.
\end{abstract}

Keywords Comic, Learning Media, Learning Motivation, Learning Outcomes, Learning Quality

\section{Introduction}

Generally, biology has been assumed as a difficult subject to learn [2-5] for students in some countries such as Indonesia [6]-[10] and Africa [11], Israel [12], and so forth. This is due to the complexity of the materials, which comprise various definitions, terms and names, which must be memorized [13,14]. Yet, learning media or sources, in developing country schools are often limited either in number or update [15]. This condition has led the low learning achievement in biology [16]-[18]. Furthermore, the lack of learning sources and the abstract concepts have also been the factors reported to cause of student difficulties in learning biology $[4,19,20]$.

One of biology difficult material in high school level is musculoskeletal system [6], [10], [13], [21]-[23]. In this topic, students are demanded to learn about skeletal anatomy, muscle, as considerable as physiological fundamental of human motion. These abstract and complicated concepts are immense constraints to deal with in encompassing musculoskeletal system materials.

In addition, the low students' interest and motivation in learning biology have also been found in high schools in Malang City East Java Province. Based on the interview results done among students, it was found that the students were lazy in reading biology materials. They would only read their book as they got a task or the quiz would be 
conducted. Biology teachers also stated that they dislike to read biology book as the package provided by government and school tended to be boring.

Biology teachers have a responsibility in exploring the learning conditions as crucial as considering the most effective approach in improving students' interest and motivation in learning science [4,24-26]. One of the efforts to elevate students' interest in science learning process is by developing various innovative learning media [27][29].

There have been many developed learning media as well as the studies discussed the effect of those media on learning process and student academic achievement $[30,31]$. Of the studies done, comic has been recognized as one of the potential media to cope with biology learning issues [32]-[36].

Various types of media can be used to help teachers deliver material in the learning process. However, in choosing the media, especially for developing countries which have economic challenges, the barriers of using technology, and poor problems [37]-[41], for the sake of teaching, it is necessary to pay attention to various aspects. These aspects are the conformity media with teaching objectives, the support of the content to the teaching materials, the ease of obtaining the media, the teachers' skills in utilizing the media, the time availability to use the media, the suitability of the media with students thinking level. This article provides information of comic development as an alternative needed to read in accordance with the necessary to create a feasible media which meets the all aspects required.

\section{Literature Review}

This study was bordered from the ideas about the complexity of musculoskeletal materials for senior high school students [6], [10], [13], [21]-[23]. This condition has limited their profound understanding. Moreover, the limited media available has also led the low students achievement [16]-[18].

Medium is an intervening means, instrument or agency to carry out or transmit information [42]. It enables representations and images of the world to be communicated indirectly. To go further, media education purpose is to develop critical thinking, perception, interpretation, analysis, and evaluation of text media [43]. The term is also used as synonymous with, or part of, media education. Not only do media allow people to interpret and create judgments as consumers of media, but it also leads them to become media producers in their own right.

Comics have been considered as a potential learning media to deliver various subjects to students $[24,26,34,44,45]$. The common contents covered in comics are adventure story, fantasy adventure, roles, humor, family drama, history and biography, picture presentation [46]. This visual learning media is able to convey immediate visceral meanings which cannot be done with conventional texts [47]. Moreover, it can be considered as one of printed media which represents a unique form of entertainment in education which create a fun-to-read nuance [48]. The roles contained in comic are also interesting aspect to encourage students to be more engaged to the materials addressed to deliver.

By considering these potentials, teachers can develop comic as a form of innovative media to deliver a certain material as well as increasing students' interest in learning science [27]-[29]. Thus, in turn, students' achievements will be elevated.

\section{Theoretical Framework}

Not only does the comic play as a communication tool which encourages students' intrinsic motivation, but it also cultivates students' interest in learning materials [31], [49]-[52], including science and biology [34], [35], [53]. Furthermore, comic enables teachers to deliver knowledge to students through visual design in terms of art value [24], [36], [54], [55]. This visual design, as the consequences, will lead the students to be attracted to the knowledge delivered and empower them in constructing their own comprehension [49], [50], [52].

To be more detail, the visual design combines pictures and words in a comic. As comic is able to drive these both components to create a certain narration, this places comic as a better device compared to text book in facilitating a knowledge delivering [31], [35], [36], [50], [56]. The narration can be arranged into a story which describes science phenomena that occurred in daily activities, thus, it can contextualize the concepts learnt [49]. Moreover, the information presented in pictures will be saved in students' long-term memory [50], [51], [56].

It is interesting that, actually, comic has been used in learning process since decades ago, however, it is often to be criticized by parents, society, and teachers [44], [45]. Thus, in the last several years, comic has been stated as the unoptimized popular media in learning [50]. Nevertheless, nowadays comic has been considered in education field. Educators in various levels are designing new ways in comic-aided teaching [35], [56], [57]. This stimulates researchers to study the potential of using comic in learning several subjects such as history [57], chemistry [56], medical [50], and biology [24], [30], [31], [45].

Notwithstanding that there were various studies related to comic utilizing in learning process, yet the study of developing comic for the thorough biology subject materials in high school is not conducted, especially in musculoskeletal system topic. Hence, this study aimed at developing biological comic for musculoskeletal materials as well as observing its potential in improving learning 
achievement of junior high school students.

\section{Materials and Method}

This study was research and development. The product developed was science comic in human musculoskeletal system topic as a learning media for eighth graders. The sub-materials covered in comic were structure and skeletal function, structure and articulation function, structure and muscular function, and human musculoskeletal disorder.

The research and development model referred was the model initiated by Gall et al. (2006). As served in Figure 1, there were ten steps in this model i.e. (1) potential and problem identification. In this step, an identification of problem found in the school was done as well as analyzing the potentials found among students. (2) Data collection. In this point, the data of students' early conditions in terms of their strengths and weaknesses were collected. (3) Product design, in which the researchers designed the media prototype developed. (4) Design validation. The feasibility and content accuracy of the prototype made was assessed by validators. (5) Design revision. The researchers revised the prototype media assessed by validators. (6) Preliminary field testing. The revised prototype was tested to small group of students. (7) Operational product revision. Researchers revised the prototype based on preliminary field testing results. (8) Main field testing. The revised prototype was tested to the wider subjects. (9) Main product revision. Revision process conducted based on the findings of main field testing. (10) Dissemination. The product resulted was produced and disseminated, hence, it reached the larger-scale of society. Problem identification and data collection were conducted in one of private junior high schools in Malang City. Meanwhile, the media validation was completed by two expert validators (associate professors). The design revision of the science comic was based on those two expert validation results.

The developed comic was served on A5 sized papers with $210 \mathrm{~mm}$ width and $148 \mathrm{~mm}$ height. The comic was set in portrait. The all parts of the comic were coloured in black and white except some certain illustrations which needed to be painted in another colours. This comic was produced as printed media and developed in three main parts, namely, introduction, main content, and closing.

Several materials were collected as the references in comic production. The materials were natural science book package for eighth graders which contained of human musculoskeletal system, a syllabus which described the basic competence need to be achieved by students, as well as an example of comic-based learning media entitled DANI as the comparison of comic format. Besides those resources, several editing software were also inventoried to ease the researchers in developing the comic better. The software mentioned were a) Adobe Photoshop CS 3 to aid the editing of picture scanning results of comic sketches; $b$ ) Microsoft Office Word 2010 to integrate the materials in comic.

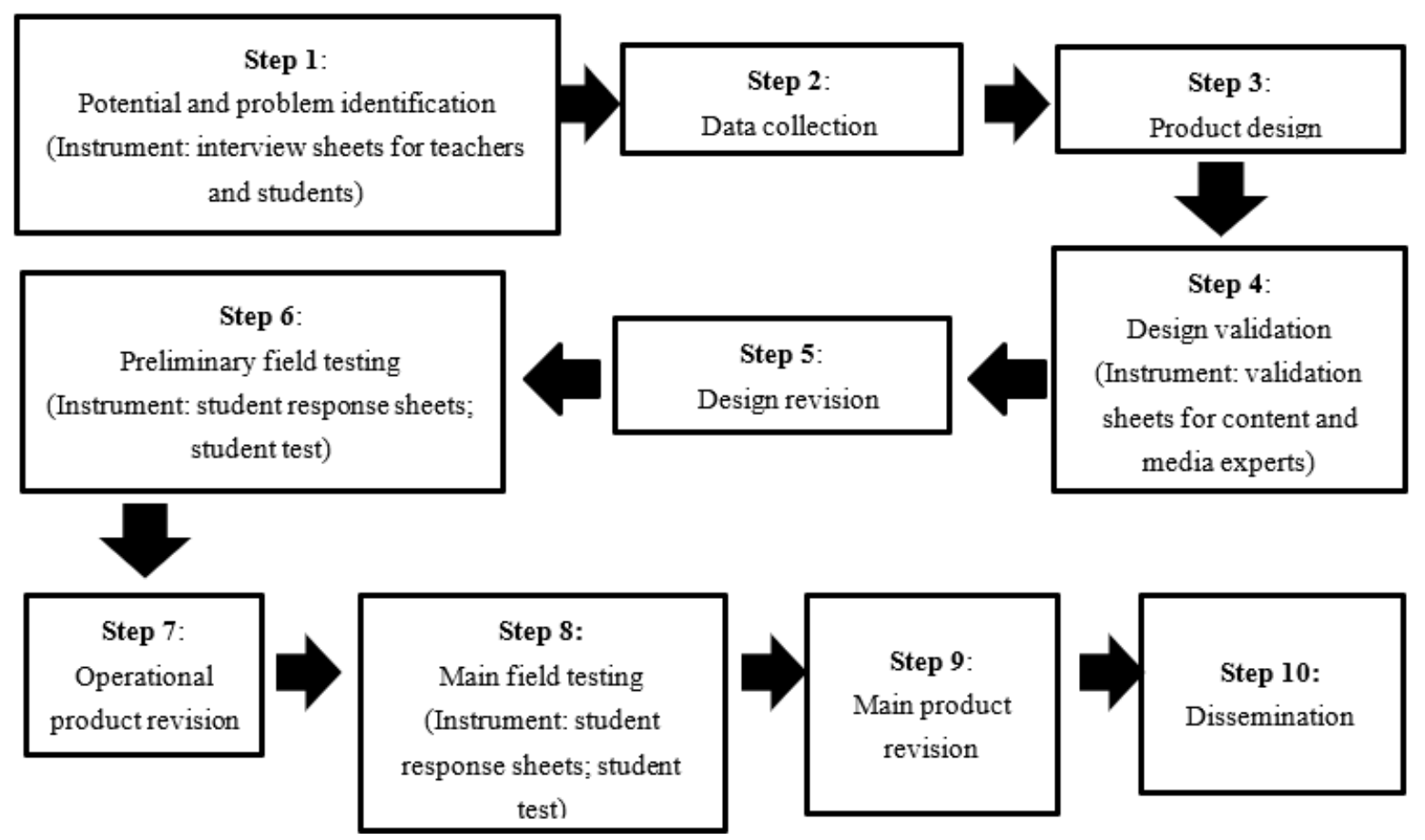

Figure 1. The flow chart of research and development steps initiated by Gall et al. (2006) 
The both product trials were done in small scale and implementation trial in terms of large-scale trial (after product revision based on the findings found during small-scale trial). The small-scale trial was done in one of SMPN (Sekolah Menengah Pertana Negeri/governmental junior high school) in Malang in which the participants were ten students of eighth graders. Meanwhile, the large-scale trial was conducted in three schools in which the participants were 30 students of eighth graders. The subjects chosen based on Simple Random Sampling technique. In addition, One Group Pretest-Posttest was utilized as the experimental design in the two product trials.

The instruments used for the data collection in this study were (a) interview sheets for teachers and students which given in step (1); (b) validation sheets for content and media experts which were given in step (4); (c) the sheets of students' response on the developed product which were given in steps (6) and (8); and (d) the test of students' learning outcome which were given in step (6) and (8).

The validation comment results from materials and media experts as well as the students' responses of the two scale trials were analyzed qualitatively. Furthermore, the expert validation data and the results of students learning achievement tests from the two scale trials were analyzed quantitatively. The expert validation results, small-scale trial test results, and students' responses were analyzed quantitative-descriptively in percentage; while the learning achievement results gained from large-scale trial were calculated using paired samples t-test $(\alpha=5 \%)$. The Shapiro-Wilk test was done before the t-test was conducted to check whether the data met the requirement of normal distribution.

\section{Results}

This study was purposed to develop a learning media which can solve biology learning issues in junior high school level. Through an identification process of the potential issues and data collection, it was found that the availability of learning media in several schools in Malang was still limited, particularly, those which can stimulate students' interest in reading science. Moreover, the students felt that picture learning media was not feasible in supporting them to comprehend their learning materials. Through the data collection, it was found that teachers expected there would be a media that aids them to deliver human musculoskeletal material, thus, easing the students to understand the concepts. Besides that, teachers did hope that the media could cultivate the students' interest mainly in reading. Developing comic as a learning media which discusses human musculoskeletal system is an alternative solution in fulfilling teachers' expectations. It was also expected that the comic served illustration pictures which would attract the students to learn.

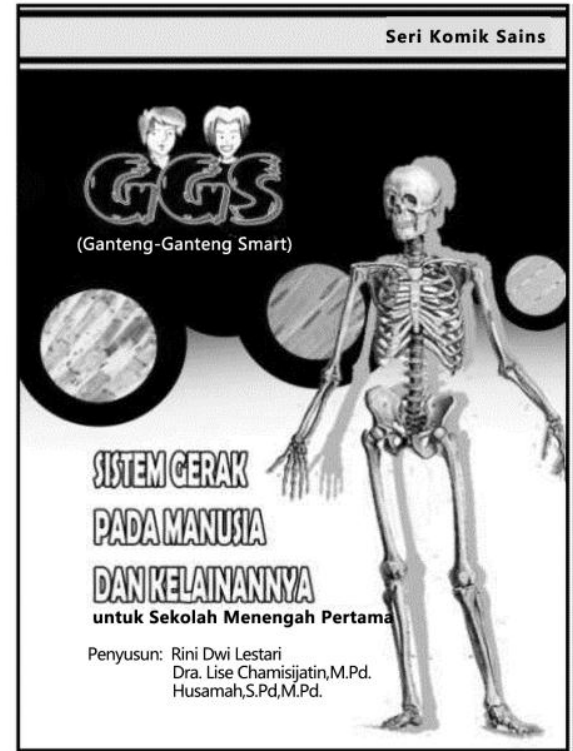

(a)

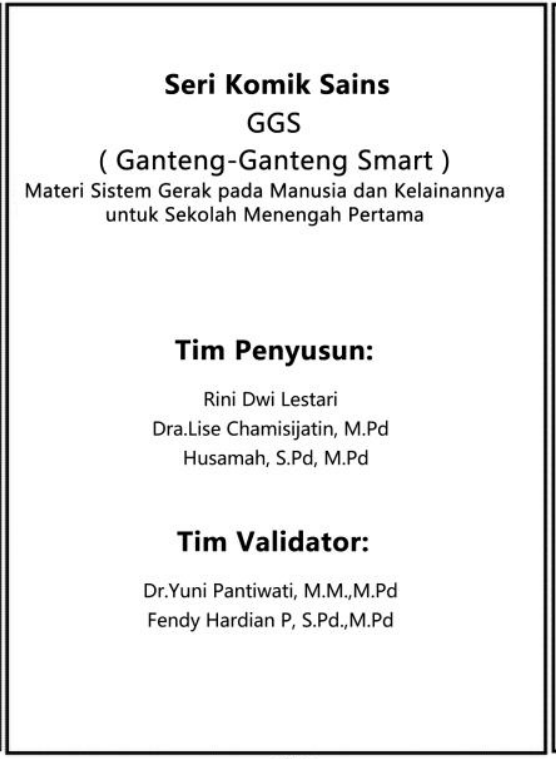

(b)

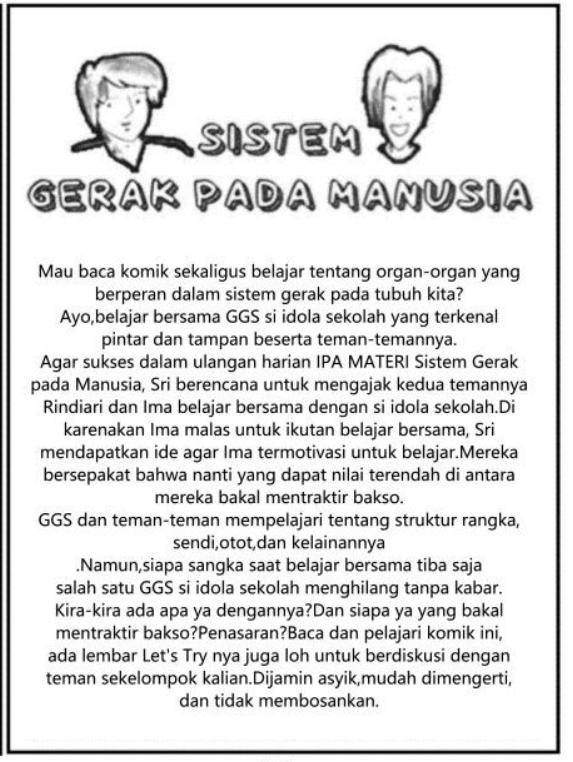

(c)

Figure 2. (a) The design of front cover; (b) Inner cover; and (c) Back cover 
The comic developed in this study was composed of three parts, i.e. introduction, main contents, and closing. The introduction covered four parts: 1) comic cover (front and inner covers served in Figure $2 \mathrm{a}$ and $2 \mathrm{~b}$, materials separation cover served in Figure 3, while the back cover served in Figure 2c); 2) preface (Figure 4a); 3) table content (Figure 4b); and 4) roles and characters (Figure 4c).

The main content contained of picture illustrations and photos attributed with sequenced conversation in balloon. The detail content of the comic covered: 1) human musculoskeletal system material (the example of material design is served in Figure 5a); and 2) "Let's Try" sheet which continued of trial or observation activities which can be done in a group to prove the concept rightness or to find a new concept (Figure 5b). The closing was arranged of references list.

After the preliminary product design was completed, the product then was validated by content and media experts. The summary of the content and media expert validation results are served in Table 1 and Table 2 respectively. Based on Table 1, the content expert validation result was as high as $81.25 \%$ which means that the media was categorized as 'good' with the description 'possessing the validity level and need to minor revision'. This indicated that the comic developed as learning media in human musculoskeletal material for eighth graders was feasible to use. On the other hand, the media expert validation results only reached $65.56 \%$ which was categorized as 'fair' with the description was 'possessing fair validity level and required major revision' (Table 2 ).

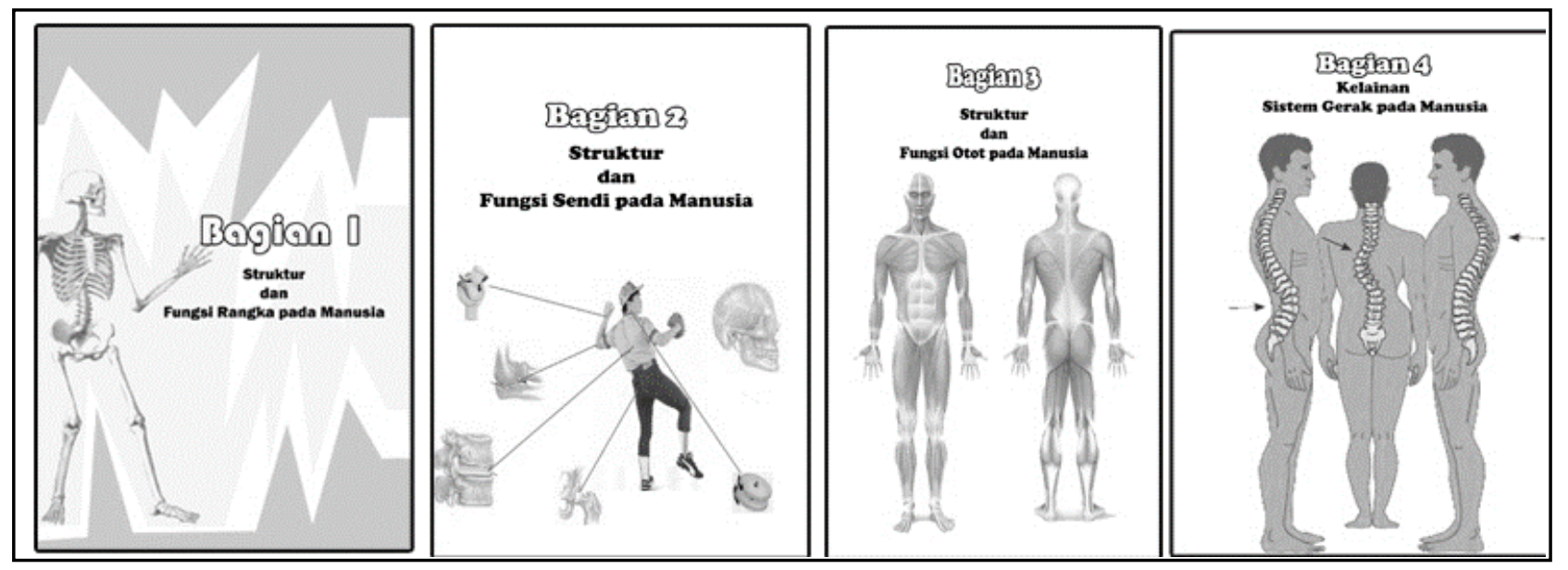

Figure 3. The design of sparation cover which separated each material

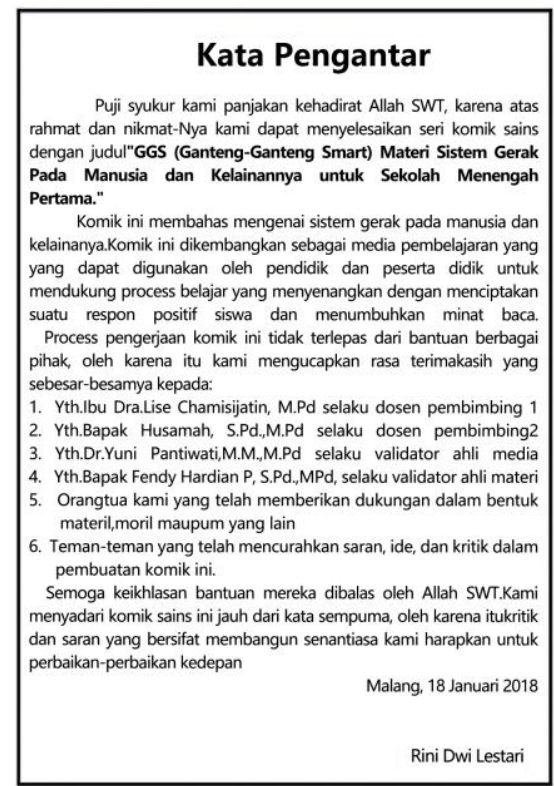

(a)

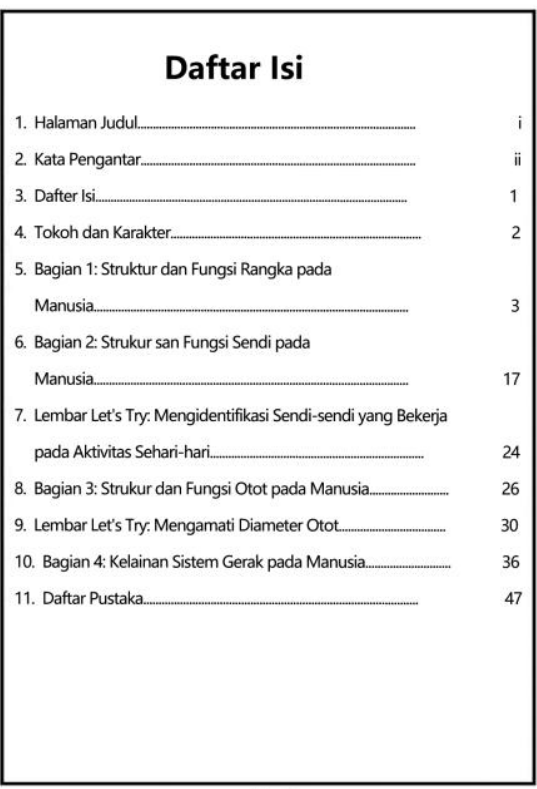

(b)

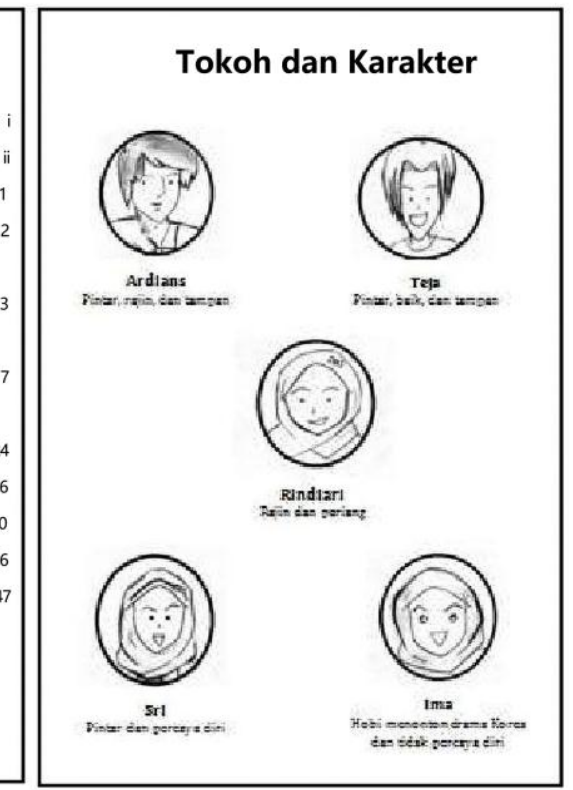

(c)

Figure 4. (a) Preface design; (b) Table content; and (c) Roles and Characters 


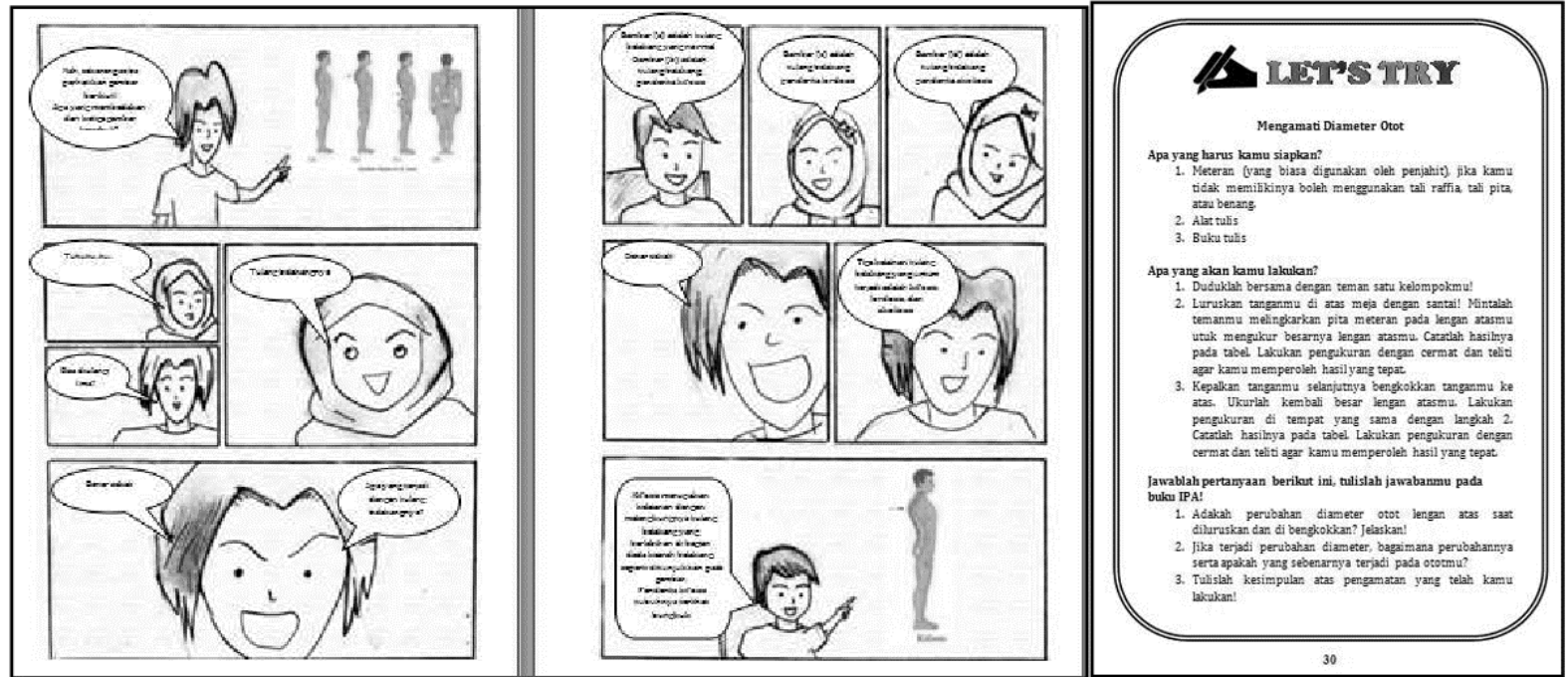

(a) (b)

Figure 5. (a) The design of material presentation; and (b) "Let's and Try" sheet

After the validation process, the next step was design revision. The design revisions were based on the comments and suggestions given by the content and media experts which are served in Table 3,4, and 5. The product revision results are also served in the same tables. The re-validation was conducted after the product was revised to clarify if the product quality was improved from the media point of view. The validation results of media expert have improved and reached $80 \%$, which means that the media was 'good' (Table 2).

The next step was small-scale trial. This trial was done on eighth graders for $2 \times 40$ minutes, which was started with working on pretest and continued to learn science comic and closed with doing the posttest and fulfilling the questionnaire prepared for students. The obtained data from the small-scale trial showed that the mean value of posttest was higher than the pretest $(95>69)$. There was an improvement of the posttest mean compared to the pretest as high as 26 points. In addition, the percentage of students' response on comic media has reached 96.77 (Table 6). This percentage was categorized as 'very good'. The suggestions came from students for the comic media was 'some of skeletal pictures in the comic were unclear, thus, it is better to make them clearer'. This comment was referred to revise the comic before the next developing steps were conducted.

Table 1. The summary of content expert validation results

\begin{tabular}{|c|c|c|}
\hline No. & Aspect & Percentage (\%) \\
\hline 1 & $\begin{array}{c}\text { The suitability of content to the basic } \\
\text { competence expected }\end{array}$ & 80 \\
\hline 2 & The content precision & 80 \\
\hline 3 & The content update & 85 \\
\hline 4 & Encourage curiosity & 80 \\
\hline \multicolumn{2}{|c|}{ Mean } & 81.25 \\
\hline
\end{tabular}

Table 2. The summary of media expert validation results

\begin{tabular}{|c|c|c|c|}
\hline \multirow{2}{*}{ No. } & \multirow{2}{*}{ Aspect } & \multicolumn{2}{|c|}{ Percentage (\%) } \\
\cline { 3 - 4 } & & $\begin{array}{c}\text { Before } \\
\text { revision }\end{array}$ & After revision \\
\hline 1 & Size & 60 & 80 \\
\hline 2 & Cover design & 70 & 80 \\
\hline 3 & Content design & 66.67 & 80 \\
\hline \multicolumn{2}{r|}{ Mean } & 65.56 & 80 \\
\hline
\end{tabular}


Table 3. The comments and suggestions of media expert (Re-validation)

\begin{tabular}{|c|c|}
\hline Comments/ Suggestions & Follow up \\
\hline $\begin{array}{l}\text { The character faces are not } \\
\text { interesting }\end{array}$ & $\begin{array}{l}\text { The characters' faces were improved by smoothing the picture textures as well as increasing their brightness } \\
\text { and contrast in order to looks more interesting. }\end{array}$ \\
\hline
\end{tabular}

Table 4. The comments and suggestions of media expert

\begin{tabular}{|c|l|l|}
\hline No & Comments/ Suggestions & Follow up \\
\hline 1 & $\begin{array}{l}\text { The comic title is not } \\
\text { communicative. }\end{array}$ & Changed the comic title with the more communicative one. \\
\hline 2 & $\begin{array}{l}\text { Check the theory about comic } \\
\text { size. }\end{array}$ & $\begin{array}{l}\text { Generally, there is no certain provision about the size of comic, this due to the comic size } \\
\text { published are various based on the different publishers. For example, the common size of } \\
\text { American comics is tabloid (11 x 17 inch). Meanwhile, the Japanese manga were often sized } \\
\text { in B4 (180 x 270mm). The comics in Indonesia have been published in A5 or less size, or } \\
\text { even a little wider. The researchers chose to print the comic in A5 size (148 x 210 mm), in } \\
\text { accordance with the common comic published in Indonesia. Utariyanti, Wahyuni, and } \\
\text { Zaenab (2015) in their article reported that the comic-based media they developed was } \\
\text { printed in A5 size. }\end{array}$ \\
\hline 3 & $\begin{array}{l}\text { The pictures are not interesting } \\
\text { The pictures in comic were improved by re-drawing in more interesting way. }\end{array}$ \\
\hline 4 & $\begin{array}{l}\text { The human musculoskeletal } \\
\text { disorder is not appear in the front } \\
\text { cover illustration. }\end{array}$ & $\begin{array}{l}\text { Eliminated the illustration picture of muscle preparation results on the comic front cover due } \\
\text { to its irrelevancy and changed it with the illustration of human musculoskeletal system } \\
\text { disorder in order to be more representative in describing the materials discussed in the comic. }\end{array}$ \\
\hline 5 & $\begin{array}{l}\text { The role characters are unclear. } \\
\text { alarified the characters and roles by improving the role faces in order to meet the suitability } \\
\text { of the characters as well as sharpening in writing the roles' characters }\end{array}$ \\
\hline
\end{tabular}

Table 5. The comments and suggestions of content expert

\begin{tabular}{|c|l|l|}
\hline No. & Comments/ Suggestions & Follow up \\
\hline 1 & $\begin{array}{l}\text { The size of pictures and descriptions for skeletal and } \\
\text { mucular materials need to be enlarged }\end{array}$ & $\begin{array}{l}\text { Enlarged the pictures and descriptions for skeletal and muscular } \\
\text { materials. }\end{array}$ \\
\hline 2 & $\begin{array}{l}\text { The material of musculoskeletal system disorder needs } \\
\text { to be added; thus, it meets the basic competence 4.1 }\end{array}$ & Add the material related to musculoskeletal system disorder. \\
\hline 3 & $\begin{array}{l}\text { Increase the number of daily issues of musculoskeletal } \\
\text { disorder as the contextual examples }\end{array}$ & $\begin{array}{l}\text { Increase the examples of daily issues of musculoskeletal system disorder } \\
\text { i.e. osteoporosis which commonly occurred on adulterers as } \\
\text { considerable as an example of the elders habit in sunbathing their babies } \\
\text { in the morning which is a good effort in keeping the musculoskeletal } \\
\text { system in a health condition. }\end{array}$ \\
\hline 4 & $\begin{array}{l}\text { It is important to add the information about the } \\
\text { endeavors to keep the musculoskeletal system healthy } \\
\text { (suitable with basic competence 4.1) }\end{array}$ & $\begin{array}{l}\text { Add the lack information of several efforts to keep the musculoskeletal } \\
\text { system healthy. }\end{array}$ \\
\hline
\end{tabular}


The large-scale trial was conducted after the product revisions were completed. The large-scale trial involved three schools in Malang. The statistical test of the students' test results are served in Table 7. Based on the table, it can be seen that the statistical value obtained from Shapiro Wilk test was 0.930 with the $p$ value $=0.001<\alpha$. In the other words, the data were not normally distributed, thus the paired samples t-test could not be done. As the alternative, $\mathrm{Z}$ value $(7.296$ with $p$ value $=0.001<\alpha)$ was obtained from Wilcoxon Signed Ranks test. This indicates that the students achievement after joining the comic-aided learning has improved significantly compared to their learning results without comic. In line with this finding, the students' response, from three schools, on comic always reached more than $90 \%$. Thus, the comic developed was categorized as 'very good'.

Table 6. The summary of students' response in small-scale trial

\begin{tabular}{|c|c|c|}
\hline No. & Aspect & Percentage (\%) \\
\hline 1 & Interest & 95.33 \\
\hline 2 & Material & 95 \\
\hline 3 & Language & 100 \\
\hline \multicolumn{2}{|c|}{ Mean } & 96.77 \\
\hline
\end{tabular}

Table 7. The summary of statistical test results of learning achievement data in large-scale trial

\begin{tabular}{|c|c|c|c|}
\hline Test & $\begin{array}{c}\text { Statistical } \\
\text { values }\end{array}$ & $\begin{array}{c}\text { Degree of } \\
\text { freedom }\end{array}$ & $\boldsymbol{p}$ value \\
\hline Shapiro-Wilk & 0.930 & 72 & 0.001 \\
\hline $\begin{array}{c}\text { Wilcoxon Signed } \\
\text { Ranks }\end{array}$ & 7.296 & - & 0.000 \\
\hline
\end{tabular}

Table 8. The summary of students' response in large-scale trial

\begin{tabular}{|c|c|c|c|c|}
\hline \multirow{2}{*}{ No } & \multirow{2}{*}{ Aspect } & \multicolumn{3}{|c|}{ Percentage (\%) } \\
\cline { 3 - 5 } & & School-A & School-B & School-C \\
\hline 1 & Interest & 90.0 & 95.4 & 90.0 \\
\hline 2 & Material & 89.5 & 96.4 & 90.5 \\
\hline 3 & Language & 93.0 & 98.5 & 93.0 \\
\hline \multicolumn{2}{|c|}{ Mean } & 90.83 & 96.76 & 91.67 \\
\hline
\end{tabular}

\section{Discussion}

The findings obtained in this study are in line with the previous reports. Lin and Lin (2016) reported that the use of science comic was better in improving students' learning achievement compared to science text. Similarly, the other study reports stated that comic plays an important role in attracting and constructing positive attitude in students toward biology learning [31]. Besides that, comic has also increased students' contribution in learning, improved students' reading motivation, as significant as helped them in memorizing learning content, and creating more cheerful learning processes [24], [31], [36], [49], [50].

The tested comic was then revised again in order to be in accordance with the suggestions given by students based on the large-scale trial. The comments and suggestions were: 1) it is necessary to re-check the words used in the comic as there were the typos found; 2) it is better to add the plot reading guidance; thus, the readers will not confuse in choosing reading plot.

The comic was developed in this study as the learning media in musculoskeletal system material for eighth graders. Based on the product trial done, it can be known that the comic implementation as learning media was able to improve the students' learning achievement. Learning achievement is one of the indicators determines a learning process [59]-[61]. The better the learning process the better the learning achievement enacted by students. The significant difference of student learning achievements before and after joining the learning process indicated that the implementation of the comic developed was able to improve learning quality.

The findings of this study are expected to provide useful information for teachers as considerable as some parties responsible for issuing the educational policies. This can be a trigger that stimulates teachers' innovations in developing biology learning media in more creative forms in the future. As the issues related to biology, particularly in musculeskeletal material, keep emerging such as ethics [62], educator demand [11], the limited literatures [15], not only does the availability of the effective media can facilitate the students' learning processes better, but it possibly also, indirectly, minimize the use human cadaveric dissection which has been the main feature of anatomy learning. The proven effectiveness of the media implementation, the decision maker parties in educational policies can refer the article findings as the basic information undergirding their policy direction in term of train their teachers to develop learning media, and so forth.

\section{Conclusions}

Comic as the learning media in human musculoskeletal system for eighth graders was developed in this study. The content and media validation results of the product developed were $81.25 \%$ and $80 \%$ respectively, which means that the product was categorized as 'good'. The small-scale trial results showed that there was an increase of mean values achieved by students from 69 to 95 . This result was in line with the results gained in large-scale trial which indicated that there was a significant difference between the students' pretest and posttest $(Z=7.296, p$ value $=0.000$ ).

This study results showed that the implementation of comic as the learning media has a potential in improving the quality of biology learning processes. The quasi experimental study is necessary to be conducted to observe the effect of this learning media implementation deeper. The study of positive effect of comic utilization in learning 
is also needed to be conducted which focused on the other parameters such as learning motivation, thinking skills, and students' learning retention.

\section{Acknowledgments}

We would like to acknowledge the supports given by several parties in research and article writing completion. Sincere gratitude is extended to the experts (validators) who validated the comic. We also appreciate the school principals, teachers, and students who participated in comic trial.

\section{REFERENCES}

[1] M. D. Gall, J. P. Gall, and W. R. Borg, Educational-Research: An Introduction, 7th ed. Boston: Pearson Education, Inc., 2006.

[2] L. Mnguni, "The curriculum ideology of the South African secondary school Biology," South African J. Educ., vol. 33, no. 2, pp. 1-11, 2015 .

[3] M. Sanders and D. Makotsa, "The possible influence of curriculum statements and textbooks on misconceptions: The case of evolution," Educ. as Chang., vol. 20, no. 1, pp. 216-238, 2016.

[4] A. B. Etobro and O. E. Fabinu, "Students' perceptions of difficult concepts in Biology in senior secondary schools in Lagos State," Glob. J. Educ. Res., vol. 16, pp. 139-147, 2017.

[5] R. de Villiers, "Student teachers' views: what is an interesting Life Sciences curriculum?," South African J. Educ., vol. 31, no. 4, pp. 535-548, 2016.

[6] A. Hidayat and A. Mujahiduddien, "Pembelajaran bentuk sendi tulang manusia menggunakan konsep augmented reality," J. Siliwangi, vol. 3, no. 1, pp. 204-208, 2017.

[7] I. W. Pangestika, M. Ramli, N. Nurmiyati, and S. Sapartiwi, "Hasil belajar biologi siswa kelas XI MIPA melalui penerapan dialog Socrates," in Proceeding Biology Education Conference, 2017, vol. 14, pp. 305-310.

[8] T. Permana, "Penerapan model team assisted individualization dengan pemanfaatan chart untuk meningkatkan hasil belajar siswa kelas XI pada pembelajaran struktur jaringan hewan," Semarang, 2010.

[9] E. S. Wahyuni, G. Indriati, and A. Maizeli, "Pengembangan handout berrgambar disertai peta konsep pada materi jaringan hewan untuk SMA," Pendidik. Biol., vol. 1, no. 1, pp. 1-6, 2014.

[10] L. Triani, S. Wahyuni, E. Purwanti, A. M. Hudha, D. Fatmawati, and H. Husamah, "Pembelajaran I-CARE berbantuan praktikum: Peningkatan problem-solving skills dan hasil belajar siswa pada materi jaringan hewan," J. Inov. Pendidik. IPA, vol. 4, no. 2, pp. 158-168, 2018.

[11] B. Kramer, N. Pather, and A. O. Ihunwo, "Anatomy:
Spotlight on Africa," Anat. Sci. Educ., vol. 1, no. 3, pp. 111$118,2008$.

[12] R. Lazarowitz, S. Penso, and R. Lazarowitz, "Learning Biology Concepts Concepts," J. Biol. Educ., vol. 26, no. May 2013, pp. 37-41, 1992.

[13] M. Ulfah, "Optimalisasi hasil belajar IPA tentang sistem gerak pada manusia melalui metode diskusi dengan tehnik pembelajaran tutor sebaya," Dinamika, vol. 3, no. 1, pp. 1924, 2012.

[14] B. Ogunkola and D. Samuel, "Science Teachers' and Students' Perceived Difficult Topics in the Integrated Science Curriculum of Lower Secondary Schools in Barbados," World J. Educ., vol. 1, no. 2, pp. 17-29, 2011.

[15] B. M. Modisaotsile, "The failing standard of basic education in South Africa," Policybrief, no. 72, pp. 1-7, 2012.

[16] H. Hasibuan and E. Djulia, "Analisis kesulitan belajar siswa pada materi virus di kelas X Aliyag Al-Fajri Tanjungbalai tahun pembelajaran 2016/2017," J. Pelita Pendidik., vol. 4, no. 4, pp. 16-24, 2017.

[17] M. U. Kusumawati, "Identifikasi kesulitan belajar materi Strukutr - Fungsi Jaringan Tumbuhan pada siswa SMA Negeri 3 Klaten kelas XI tahun ajaran 2015/2016,” J. Pendidik. Biol., vol. 5, no. 7, pp. 19-26, 2016.

[18] N. J. Mulder, A. Christoffels, T. de Oliveira, J. Gamieldien, S. Hazelhurst, F. Joubert, J. Kumuthini, C. S. Pillay, J. L. Snoep, Ö. Tastan Bishop, and N. Tiffin, "The development of computational biology in South Africa: Successes achieved and lessons learnt," PLoS Comput. Biol., vol. 12, no. 2, pp. 1-15, 2016.

[19] A. Çimer, "What makes biology learning difficult and effective: Students' views," Educ. Res. Rev., vol. 7, no. 3, pp. 61-71, 2012

[20] A. Fauzi and A. D. Corebima, "Pemanfataan Drosophila melanogaster sebagai organisme model dalam mempelajari Hukum Pewarisan Mendel," in Seminar Nasional Biologi 2016, 2016, pp. 372-377.

[21] C. Tekkaya, O. Ozkan, and S. Sungur, "Biology concepts perceived as difficult by turkish high school students," $J$. Educ. 21, vol. 21, pp. 145-150, 2001.

[22] R. E. Fadilah, S. Suratno, and D. Wahyuni, "Pengembangan bahan ajar sistem gerak manusia berbasis peta konsep dalam meningkatkan penguasaan konsep siswa kelas XI SMA di Kabupaten Jember," Pancaran, vol. 4, no. 3, pp. 41-50, 2015.

[23] M. Rahmida, "Meningkatkan hasil belajar siswa pada materi sistem gerak manusia melalui model pembelajaran kooperatif tipe teams-games-tournaments (TGT)," QUANTUM J. Inov. Pendidik. Sains, vol. 2, no. 2, pp. 101$112,2011$.

[24] S. Lin and H. Lin, "Learning nanotechnology with texts and comics: the impacts on students of different achievement levels," Int. J. Sci. Educ. ISSN, vol. 38, no. 8, pp. 1373-1391, 2016.

[25] Husamah and Y. Pantiwati, "Cooperative learning STAD-PJBL: motivation, thinking skills, and learning outcomes of biology department students," Int. J. Educ. Learn. Dev., vol. 2, no. 1, pp. 77-94, 2014. 
[26] K. Mamutse, "Pre-service science teachers' perceptions of the problems that they face in their training," in ISTE International Conference on Mathematics, Science and Technology Education, 2016, pp. 587-597.

[27] A. T. Widiansyah, S. E. Indriwati, M. Munzil, and A. Fauzi, "I-invertebrata as an android-based learning media for molluscs, arthropods, and echinoderms identification and its influence on students' motivation," JPBI (Jurnal Pendidik. Biol. Indones., vol. 4, no. 1, pp. 43-52, 2018.

[28] Y. Mehdipour and H. Zerehkafi, "Mobile learning for education: benefits and challenges," Int. J. Comput. ..., vol. 3, no. 6, pp. 93 - 101 (251-259), 2013.

[29] R. Susilana and C. Riyana, Media pembelajaran. Bandung: CV Wacana Prima, 2009.

[30] J. Pitura and D. Chmielarz, "Creating a comic strip is very creative and thanks to it we learn and remember: Student perceptions of a biology challenge in a gamified extracurricular clil project," Teach. English with Technol., vol. 17, no. 3, pp. 77-95, 2017.

[31] J. Hosler and K. B. Boomer, "Are comic books an effective way to engage nonmajors in learning and appreciating science?," CBE-Life Sci. Educ., vol. 10, pp. 309-317, 2011.

[32] M. Farinella, "The potential of comics in science communication," J. Sci. Commun., vol. 17, no. 1, pp. 1-17, 2018.

[33] B. Alverson, "Teaching with science comics," School Library Journal, 2017. .

[34] M. Koutníková, "The application of comics in science education," Acta Educ. Gen., vol. 7, no. 3, pp. 88-98, 2018.

[35] M. Tatalovic, "Science comics as tools for science education and communication: A brief, exploratory study," $J$. Sci. Commun., vol. 8, no. 4, pp. 1-17, 2009.

[36] C. M. Tribull, "Sequential science: A guide to communication through comics," Ann. Entomol. Am., vol. 110 , no. 5, pp. 457-466, 2017

[37] M. Makgato, "Identifying constructivist methodologies and pedagogic content knowledge in the teaching and learning of technology," in Procedia - Social and Behavioral Sciences, 2012, vol. 47, pp. 1398-1402.

[38] M. Makgato, "The challenges of teaching and learning technology subject at schools in South Africa: A case of INSET teachers in Mpumalanga Province," Procedia - Soc. Behav. Sci., vol. 116, pp. 3688-3692, 2014.

[39] J. Joseph, "The barriers of using education technology for optimizing the educational experience of learners," in Procedia - Social and Behavioral Sciences, 2012, vol. 64, pp. 427-436.

[40] M. Dembélé and J. Oviawe, "Introduction: Quality education in Africa-International commitments, local challenges and responses," Int. Rev. Educ., vol. 53, no. 5, pp. 473-483, 2007.

[41] J. Case, D. Marshall, and D. Grayson, "Mind the gap: Science and engineering education at the secondary-tertiary interface," S. Afr. J. Sci., vol. 109, no. 7-8, pp. 1-5, 2013.

[42] D. Buckingham, Media education literacy, learning and contemporary culture. Cambridge: Polity Press, 2003.

[43] A. Fedorov, "Media education and media literacy: Experts opinions," 2003.

[44] S. McNicol, "The potential of educational comics as a health information medium," Health Info. Libr. J., vol. 34, no. 1, pp. 20-31, 2017.

[45] L. Kruger and P. W. Sharif, "'Shoo--This book makes me to think!' Education, entertainment, and 'life-skills' comics in South Africa," Poet. Today, vol. 22, no. 2, pp. 475-513, 2005.

[46] J. Frank, "What's in the comics?," Am. Sociol. Assoc., vol. 18, no. 4, pp. 214-222, 1994.

[47] J. S. Park, D. H. Kim, and M. S. Chung, "Anatomy comic strips," Anat. Sci. Educ., vol. 4, no. 5, pp. 275-279, 2011.

[48] W. J. Brown and A. Singhal, "Entertainment-education media strategies for social change: Promises and problems," RJMC, vol. 2, no. 1, pp. 263-280, 2014.

[49] S. Lin, H. Lin, L. Lee, and L. D. Yore, “Are science comics a good medium for science communication? The case for public learning of nanotechnology," Int. J. Sci. Educ., no. May 2015, pp. 37-41, 2014.

[50] J. Muzumdar, "An overview of comic books as an educational tool and implications for pharmacy," Inov Pharm, vol. 7, no. 4, pp. 1-10, 2016.

[51] E. Ozdemir, "Humor in elementary science: Development and evaluation of comic strips about sound," Int. Electron. $J$. Elem. Educ., vol. 9, no. 4, pp. 837-850, 2017.

[52] T. L. Toh, L. P. Cheng, S. Y. Ho, H. Jiang, and K. M. Lim, "Use of comics to enhance students' learning for the development of the twenty-first century competencies in the mathematics classroom," Asia Pacific J. Educ., pp. 1-16, 2017.

[53] R. Aisyah, I. A. Zakiyah, I. Farida, and M. A. Ramdhani, "Learning crude oil by using scientific literacy comics," in Journal of Physics: Conference Series, 2017, vol. 895, no. 1, pp. 1-7.

[54] L. C. Serantes, "Young adults reflect on the experience of reading comics in contemporary society: Overcoming the commonplace and recognizing complexity," Electron. Thesis Diss. Repos., vol. 2075, 2014.

[55] E. Weitkamp and H. Featherstone, "Formative evaluation in the development of ScienceComics," J. Sci. Commun., vol. 8, no. 4, pp. 1-8, 2009.

[56] K. C. Weber, T. C. B. Saldanha, K. K. D. E. S. E, P. M. M. Santos, D. D. D. Souza, and A. Arroio, "Introducing comics as an alternative scientific narrative in chemistry teaching," Batı Anadolu Eğitim Bilim. Derg., vol. 4, no. 8, pp. 1-14, 2013.

[57] E. A.. Rozkosz and Z. Wiorogórska, "Bibliostory Educational comic stories: A social constructivist approach to media and information literacy education for children and adolescents This item was submitted to the oPUB Repository of the University of Low," in Information Literacy: Key to an Inclusive Society, S. Kurbanoğlu, Ed. Cham: Springer, 2016, pp. 718-728. 
[58] I. F. Z. Utariyanti, S. Wahyuni, and S. Zaenab, "Pengembangan media pembelajaran berbasis komik dalam materi sistem pernapasan pada siswa kelas VIII MTs Muhammadiyah 1 Malang," JPBI (Jurnal Pendidik. Biol. Indones., vol. 1, no. 3, pp. 343-355, 2015.

[59] S. D. Ramadani, A. Fauzi, I. Sukmawati, and A. D. Corebima, "Perbandingan potensi strategi pembelajaran cooperative script dan reciprocal teaching dalam memberdayakan keterampilan metakognitif, hasil belajar Biologi, dan retensi siswa SMA," in Proceedings of the 2nd Seminar \& Workshop Nasional Biologi, IPA, dan
Pembelajarannya FMIPA UM, 2015, pp. 655-661.

[60] R. Lile and C. Bran, "The assessment of learning outcomes," Procedia - Soc. Behav. Sci., vol. 163, pp. 125-131, 2014.

[61] H. Yurdugul and N. M. Cetin, "Investigation of the relationship between learning process and learning outcomes in e-learning environments," Eurasian J. Educ. Res., vol. 15, no. 59, pp. 57-74, 2015.

[62] A. Miah, "Ethical issues raised by human enhancement," Scotland, 2011. 